\title{
Lasiurus varius (Chiroptera: Vespertilionidae)
}

\author{
Gonzalo Ossa, M. Mónica Díaz, AND Rubén M. Barquez
}

www.mammalogy.org

Programa para la Conservación de los Murciélagos de Chile (PCMCh), ConserBat EIRL, Camino a la Balsa s/n, San Fabián, Biobío 386000, Chile; chalofoh@gmail.com (GO)

CONICET, PIDBA (Programa de Investigaciones de Biodiversidad Argentina), PCMA (Programa de Conservación de los Murciélagos de la Argentina), Facultad de Ciencias, Naturales e Instituto Miguel Lillo - Universidad Nacional de Tucumán. Fundación Miguel Lillo, Miguel Lillo 251, (4000) San Miguel de Tucumán, Argentina; mmdiaz@lillo.org.ar (MMD)

CONICET, PIDBA (Programa de Investigaciones de Biodiversidad Argentina), PCMA (Programa de Conservación de los Murciélagos de la Argentina), Facultad de Ciencias, Naturales e Instituto Miguel Lillo - Universidad Nacional de Tucumán. Miguel Lillo 205, (4000) San Miguel de Tucumán, Argentina; rubenbarquez@gmail.com (RMB)

Abstract: Lasiurus varius (Poeppig, 1835) is a vespertilionid bat commonly known as Chilean red bat or cinnamon red bat. L. varius is characterized by its deep reddish coloration without frosted appearance, and by the uropatagium covered with long hairs that extend beyond the trailing edge, which clearly distinguishes it from the other species in the genus. The distribution of this rare species is restricted to the southern parts of Argentina and Chile.

Key words: Argentina, Chile, Chilean red bat, insectivorous bat, Vespertilioninae

Synonomy completed 15 April 2018

DOI: $10.1093 / \mathrm{mspecies} / \mathrm{sez} 016$

Version of Record, first published online December 6, 2019, with fixed content and layout in compliance with Art. 8.1.3.2 ICZN. Nomenclatural statement.—A life science identifier (LSID) number was obtained for this publication: urn:lsid:zoobank.org:pub: 68474A08-7CB9-432E-9FC9-0162A4E1BE01

\section{Lasiurus varius (Poeppig, 1835) \\ Cinnamon Red Bat}

Nycticeius, Raff. Species prima Poeppig [spelled Pöppig], 1830: Column 217.

N[ysticeius]. varius Poeppig, 1835:451, footnote. Type locality "Antuco," Biobío, Chile.

Nycticeus Pæpingii Lesson, 1836:324. Type locality "Chili;" based on "Nycticejus prima species," Poeppig, 1830.

Nycticejus Pœpingii: Lesson, 1842:22. Name combination.

A[talapha]. varia: W. Peters, 1861:153. Name combination.

Lasiurus varius: Fitzinger, 1870:411. First use of current name combination.

[Atalapha noveboracensis] Var. (Atalapha varia): Dobson, 1878. Name combination.

[Atalapha (Atalapha) borealis] varia: Trouessart, 1897:122. Name combination.

[Lasiurus (Lasiurus) borealis] varius: Trouessart, 1904:87. Name combination.

Context And Content. Order Chiroptera, suborder Yangochiroptera, family Vespertilionidae, subfamily Vespertioninae, tribe Lasiurini, genus Lasiurus, subgenus Lasiurus. Historically, $L$. varius has been considered a subspecies or synonym of the eastern red bat L. borealis (Dobson 1878 as var. Atalapha varia; Osgood 1943; Cabrera 1958; Hall and Jones 1961; Mann Fischer 1978; Shump and Shump 1982; Koopman 1993) with a very wide distribution from Canada to Tierra del Fuego. Baker et al. (1988) separated the western red bat L. blossevillii (type locality Montevideo, Uruguay) from $L$. borealis without mentioning $L$. varius, presumably considering it as a synonym for $L$. borealis. Osgood (1943) indicated that the name varius was available for the Chilean race of $L$. borealis. It has been recognized as a distinct species (L. varius) because of its particular and differentiable pattern of pelage color and with a distribution restricted to the southern parts of Argentina and Chile (Barquez 1987; Mares et al. 1995; Barquez et al. 1999; Simmons 2005; Gardner and Handley 2008; Díaz et al. 2011, 2016; Rodríguez-San Pedro and Allendes 2016). Molecular analysis supports its recognition as a valid species (Baird et al. 2015); however, Rodríguez-San Pedro and Allendes (2016) pointed out that some Chilean authors still use the name L. borealis, despite the evidence that it is a distinct species. Synonymy follows Gardner and Handley (2008). L. varius is monotypic.

(C) 2019 American Society of Mammalogists 
Nomenclatural Notes. In their treatment of Lasiurus borealis, Shump and Shump (1982) recognized five subspecies of $L$. borealis, and considered the saline red bat $L$. salinae Thomas, 1902, as a synonym of $L$. b. varius. However, Shump and Shump (1982) did not include the type locality of $L$. salinae within the distribution of $L . b$. varius. Mares et al. (1995) tentatively recognized $L$. salinae as a distinct species after collecting specimens that were morphologically distinct (i.e., darker and browner) from $L$. borealis captured in the same mist net on the same night in the Catamarca Province of Argentina. However, Morales and Bickham (1995), in a restriction fragment analysis of the 12S RNA of Lasiurus, found that the single specimen of $L$. salinae examined (identified by Mares et al. 1995 as this taxon) had the same haplotype as specimens of L. blossevillii from Argentina. This led Barquez et al. (1999) to suggest the two are conspecific and the specimens of $L$. salinae represent a color morph of L. blossevillii. Gardner and Handley (2008) continued to recognize $L$. salinae as a distinct species, although Barquez et al. (1999) confirmed that the type of $L$. borealis salinae (BMNH [Natural History Museum, London] 2.2.5.39) is a specimen of L. blossevillii. Although L. salinae may be synonymous with $L$. blossevillii, the synonymy with $L$. varius has been rejected by the molecular analysis of Baird et al. (2015). Other common names of this species are Chilean red bat, southern red bat, and murciélago rojo peludo.

\section{DIAGNOSIS}

Lasiurus varius (Fig. 1) is distinguishable from all other species of the genus by its deep reddish coloration, lack of frosting on pelage, uropatagium that is fur-covered on the dorsal side with the hairs extending beyond the distal margin; in the other species of Lasiurus the margin of the uropatagium is almost naked, not densely furred. Geographically, L. varius is sympatric with only one species of the genus, the South American hoary bat L. villosissimus (Barquez 1987; Mares et al. 1995; Barquez et al. 1999; Galaz and Yáñez 2006; Iriarte 2008; Barquez and Díaz 2009; Muñoz and Yáñez 2009; Baird et al. 2015; Novaes et al. 2018). L. villosissimus can be distinguish from $L$. varius by its strong frosted appearance with dominant gray and yellowish colors, hairy wings, and larger body size with length of forearms 50-56 mm (Barquez et al. 1999; Galaz and Yáñez 2006; Gardner and Handley 2008; Barquez and Díaz 2009; Díaz et al. 2011, 2016). Although $L$. varius is similar in size to the southern red bat $L$. blossevillii, it is slightly larger (total length 105-118 mm versus 92-112 $\mathrm{mm}$; forearm 39-42 $\mathrm{mm}$ versus $37-41 \mathrm{~mm}$ ) and lacks the frosted appearance typical of L. blossevillii (Barquez et al. 1999; Barquez and Díaz 2009; Díaz et al. 2011, 2016).

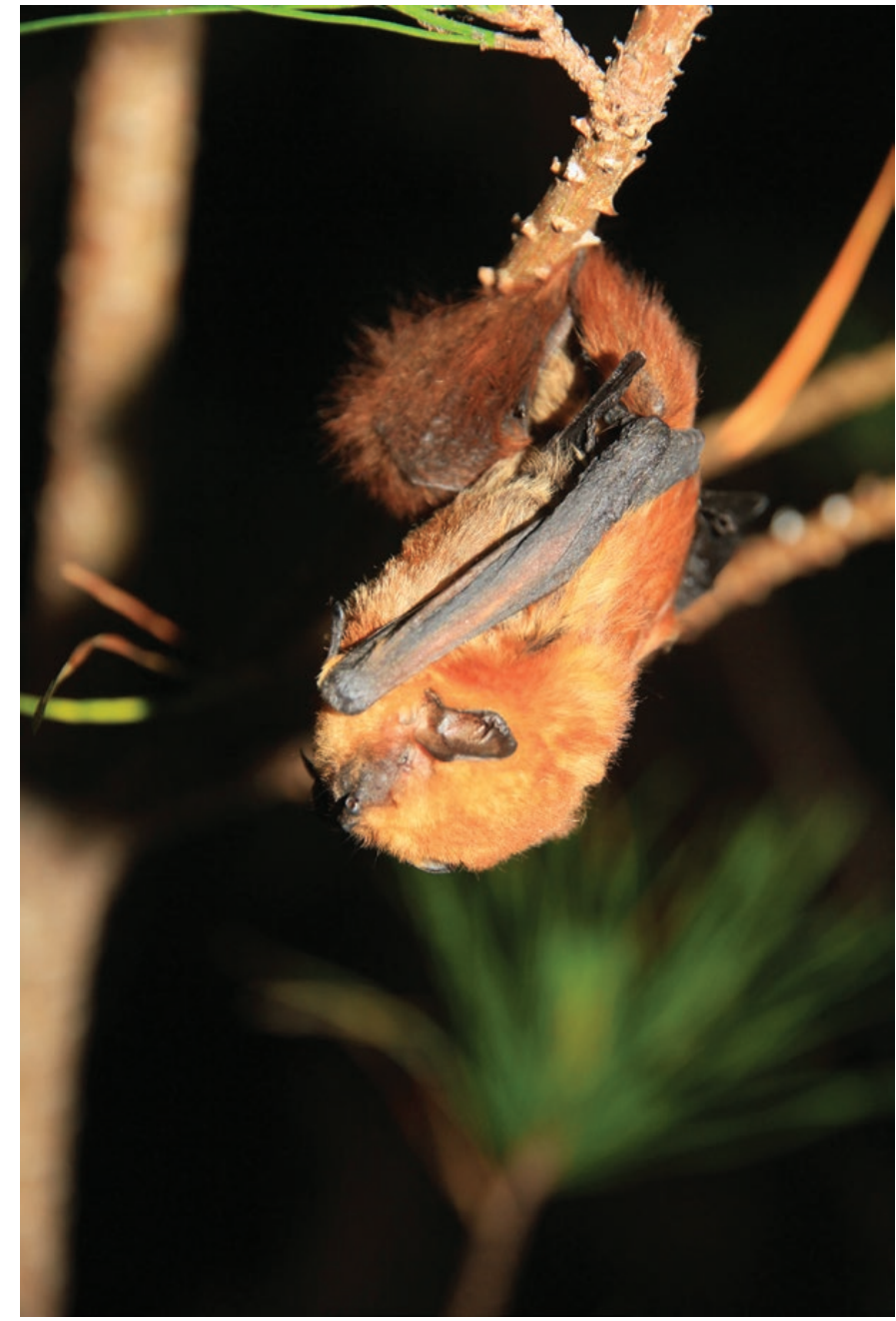

Fig. 1.-Lasiurus varius from Los Rios Region, Southern Chile. Photo by Gonzalo Ossa.

\section{GENERAL CHARACTERS}

The general color of Lasiurus varius is deep reddish and it lacks frosting (white tips) on the pelage (Fig. 1); dorsal hairs are long, tricolored, with the bases black for about $2 \mathrm{~mm}$, followed by a yellowish band that gradually darkens and terminates in the brilliant cinnamon red color that characterizes this species (Barquez et al. 1999). A yellow shoulder patch is present and more pronounced than in other species of Lasiurus; the forehead, throat, neck, and nape are pale yellow-orange; on the tricolored hairs of the venter the black band is wider and the yellow band almost disappears, being continued by a terminal cinnamon red band; the snout is short and black (Poepping 1835; Tamayo and Pérez D'Angello 1979; Barquez et al. 1999; Galaz and Yáñez 2006; Galaz et al. 2009). The ears are markedly separated, black, small, rounded, and fringed with hairs along the basal outer margin; the antitragus is high and tragus is onethird the height of the pinna; ears and lips are naked and blackish (Tamayo and Pérez D’Angello 1979; Barquez et al. 1999; Galaz 
and Yáñez 2006; Galaz et al. 2009). Wings are long and narrow. The uropatagium is covered dorsally by long hairs that extend beyond the trailing edge and ventrally is covered with yelloworange hairs on its basal one-third portion; these hairs extend to the humeral area of the plagiopatagium to the elbow, and the proximal one-half of the fifth metacarpal to the basal onefourth of the metacarpal of the fourth digit (Tamayo and Pérez D'Angello 1979; Barquez et al. 1999). Wing membranes are unornamented and black (Handley 1996).

The skull of L. varius is robust and the rostrum is short and wide. The nasals and the anterior portion of the palate are strongly invaginated so that the incisors of each side are separated by a wide gap (Fig. 2); the braincase is elevated and almost rounded with a ratio of 1.7 for the total length/braincase width. The median anterior margin of the palate is aligned with the small premolars and extends posteriorly beyond M3; the hamular process of the pterygoids extends to the height of the glenoid fossae. The caudal spine of the palate is well developed in L. varius, whereas in L. blossevillii it is undifferentiated (Barquez et al. 1999). The sagittal crest is normally reduced, although in some specimens it is evident toward the anterior part of the braincase. The lambdoid crests are slightly developed and the paraoccipital process is small but sharp. The zygomatic arches are thin and the tympanic bullae are well developed, but barely cover one-half of the cochlea (Barquez et al. 1999; Galaz and Yáñez 2006; Giménez and Giannini 2011).

Ranges of external measurements $(\mathrm{mm}, n=; 7)$ for adult specimens from Neuquén and Río Negro provinces, Argentina (Barquez et al. 1999) were: total length, 105.0-118.0; tail length, 44.0-58.0; length of hind foot, 6.0-10.0; ear length, 9.0-13.9; forearm length, 39.9-42.1. Body masses for two individuals were 9.5 and $11.0 \mathrm{~g}$ (Barquez et al. 1999). Means (and range) of external measurements ( $\mathrm{g}$ or $\mathrm{mm}$ ) for two females from Chubut Province, Argentina (Giménez et al. 2012) were: body mass, 11.3 (10.1-12.4); total length, 112.5 (104-121); head-body length, 59 (53-65); tail length, 53.5 (51-56); ear length, 13.5 (13-14); length of tragus from medial notch to tip, 6.5 (6-7); forearm length, 40.7 (40.3-41.6); length of hind foot with nail, 7.1 (6.8-7.3); length of hind foot without nail, 5.9 (5.9-5.9); length of ulna, 19.7 (19.5-20.0); thumb length, 6.7 (6.4-7.0); length of fifth finger, 56 (55-57); wingspan 300.5 (296-305); length of extended wing, 133.5 (129-138); length of third finger, 85.5 (82-89). For L. varius in Chile, Gantz and Martínez (2000) provided a total length range of 106-113 mm and mean body mass of $9.1 \mathrm{~g}$; Mann Fischer (1978) reported the following ranges for external measures $(\mathrm{mm})$ : total length 106-113, tail length 57-58, and forearm length 36-42; Osgood (1943) indicated a forearm length of 36-42 mm. Mean measurements $(\mathrm{mm} \pm S D)$ for 27 specimens, four females and 23 males, respectively, from four different regions in Chile (Biobío, Los Ríos, Los Lagos, and Metropolitana) were: body mass, $11.7 \pm 1.8,11.4 \pm 2.0$; total length, $105.8 \pm 5.2,105.4$ \pm 5.3 ; forearm length, $40.8 \pm 1.3,40.7 \pm 1.3$; tragus length, $4.5 \pm 0.6,4.6 \pm 0.6$; ear length, $10.0 \pm 0.6,10.0 \pm 0.5$; and length of the fifth finger, $49.5 \pm 2.8,49.4 \pm 2.7$ (G. Ossa, in

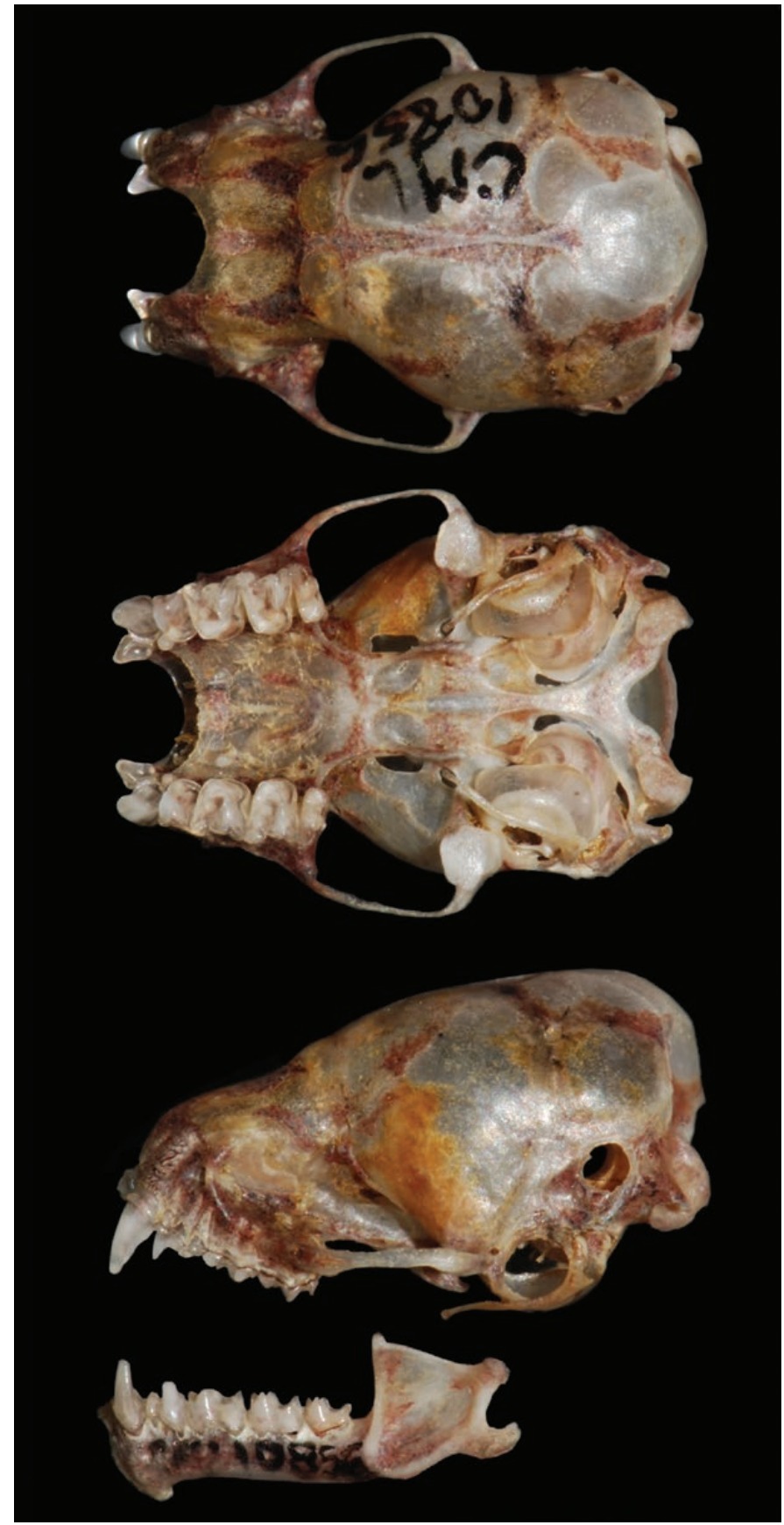

Fig. 2.-Dorsal, ventral, and lateral views of skull and lateral view of mandible of an adult male of Lasiurus varius (CML [Colección de Mamíferos Lillo, Universidad Nacional de Tucumán] 10856) from Parque Nacional Nahuel Huapi. $10 \mathrm{~km}$ al O de Villa Traful, Arroyo Media Luna, sobre ruta 65, Los Lagos Department, Neuquén Province, Argentina. Greatest length of skull is $13.38 \mathrm{~mm}$. Photo by Pablo Gaudioso used with permission.

litt.). Measurements ( $\mathrm{mm}$ ) for a male collected in San Gregorio (Chile) were: head-body length, 49; tail length, 46; length of hind foot, 7.5; forearm length, 37.5; tibia length, 18; metacarpal length of the third digit, 42; length of first phalange of the third digit, 18; length of second phalange of the third digit, 
17.5; length of metacarpal of the fourth digit, 39.5; length of first phalange of the fourth digit, 12; length of second phalange of the fourth digit, 11.5; length of metacarpal of the fifth digit, 37.5 ; length of first phalange of the fifth digit, 7.52; length of second phalange of the fifth digit, 8.5; total length of skull, 13.4 (Tamayo and Pérez D’Angello 1979).

Range of skull measurements (mm) of seven adult specimens, unless designated otherwise, from Neuquén and Río Negro provinces, Argentina (Barquez et al. 1999) were: condylobasal length, 12.2-12.9; least interorbital breadth, 5.96.1; zygomatic breadth, 9.6-9.8; greatest length of skull, 12.813.4; postorbital constriction, 4.3-4.7; breadth of braincase, 7.5-8.0; length of maxillary toothrow, 4.5-4.7; palatal length, 5.3-5.9 ( $n=; 6)$; mastoid breadth, 7.0-8.2; length of mandibular toothrow, 5.3-5.4; length of mandible, 9.7-10.0; width across canines, 5.0-5.4; width across molars, 6.1-6.5. Mean cranial measurements $(\mathrm{mm} ; \pm S D$ and parenthetical range) of five adult specimens from the same provinces (Giménez and Giannini 2011) were: condylobasal length, $12.91 \pm 0.08$ (12.85-13.04); zygomatic breadth, $9.67 \pm 0.18$ (9.49-9.93); height of braincase, $5.85 \pm 0.16(5.62-6.06)$; mastoid breadth, $7.92 \pm 0.11$ (7.77-8.04); maximum external width between left and right upper molars, $6.26 \pm 0.23$ (5.93-6.55); length of maxillary toothrow, from the anterior margin of the canine to the posterior margin of the last molar, $4.66 \pm 0.08$ (4.57-4.79); postorbital constriction, $4.66 \pm 0.09$ (4.52-4.74); length of rostrum, $2.67 \pm 0.10$ (2.54-2.82); upper canine length, $2.18 \pm$ 0.32 (1.62-2.41); length of upper third premolar, $1.37 \pm 0.16$ (1.16-1.51); mandible body height at lower third premolar, $1.42 \pm 0.12(1.26-1.59)$; lower canine length, $2.02 \pm 0.17$ (1.83-2.22); length of mandibular toothrow, from the anterior margin of the canine to the posterior margin of the last molar, $5.37 \pm 0.06(2.74-5.45)$; coronoid process height, $2.92 \pm 0.26$ (2.74-3.39).

Cranial measurements $(\mathrm{mm})$ of a female from Chubut Province, Argentina (Giménez et al. 2012) were: condylobasal length, 13.32; zygomatic breadth, 9.77; height of braincase, 5.74; cranial width, 8.14; palate width between lingual edge of upper third molars, 6.65; upper toothrow length (from the anterior margin of the canine to the posterior margin of the last molar), 4.73; lower toothrow length, 4.76; postorbital constriction, 3.18; rostrum length, 5.69; palatal length, 2.29; upper canine length, 5.36; lower canine length, 1.52; width between upper canines, 9.91; third upper premolar length, 1.45; mandible height, 5.43; coronoid height, 3.17 (the mandible length of 2.08 was erroneously indicated).

For L. varius in Chile, Mann Fischer (1978) provided the following range of measurements $(\mathrm{mm})$ : total length of skull, 11.9-12.7; basal length of skull, 11.5-11.8; zygomatic width, 8.6-9.2. Cranial measurements $(\mathrm{mm})$, some not conventional but explained by Tamayo and Pérez D'Angello (1979) in their article, for a male collected in San Gregorio (Chile) were: total length of skull, 13.4; condylobasal length, 11; palatal length, 5.5, postpalatal length, 5.7; postmolar length, 9; mandibular length, 8.5; tympanic bulla length, 3.7; frontal breadth, 4.7; braincase breadth, 7.8; rostrum breadth, 5; palatal breadth, 6.6; mandibular breadth (taken as the maximum width of the mandible between the outermost point of the inferior border of each hemimandible), 7.5; upper toothrow length, 4.5; lower toothrow length, 5.3.

\section{DISTRIBUTION}

Lasiurus varius is known from central and southern Chile, and southern Argentina (Fig. 3; Redford and Eisenberg 1992; Barquez et al. 1999; Gardner and Handley 2008). In Chile, $L$. varius was reported from Ovalle, Coquimbo $\left(30^{\circ} 34^{\prime} \mathrm{S}\right)$ to Tierra del Fuego (54 $7^{\circ}$ 'S) (Koopman 1967; Rau and Yañez 1979; Tamayo and Pérez D'Angello 1979; Rodríguez-San Pedro and Allendes 2016). In Argentina, it is distributed from Chos Malal, Neuquén Province $\left(37^{\circ} 22^{\prime} \mathrm{S}\right)$, south to Los Glaciares National Park, Santa Cruz Province (50 6'S - Barquez 1987; Mares et al. 1995; Barquez et al. 2013; Udrizar Sauthier et al. 2013; Díaz et al. 2017). L. varius is distributed in the forests and open steppe areas of the Patagonia (Barquez et al. 1999, 2013; Udrizar Sauthier et al. 2013). Gardner and Handley (2008) indicated the presence of $L$. varius in the Argentine part of Tierra

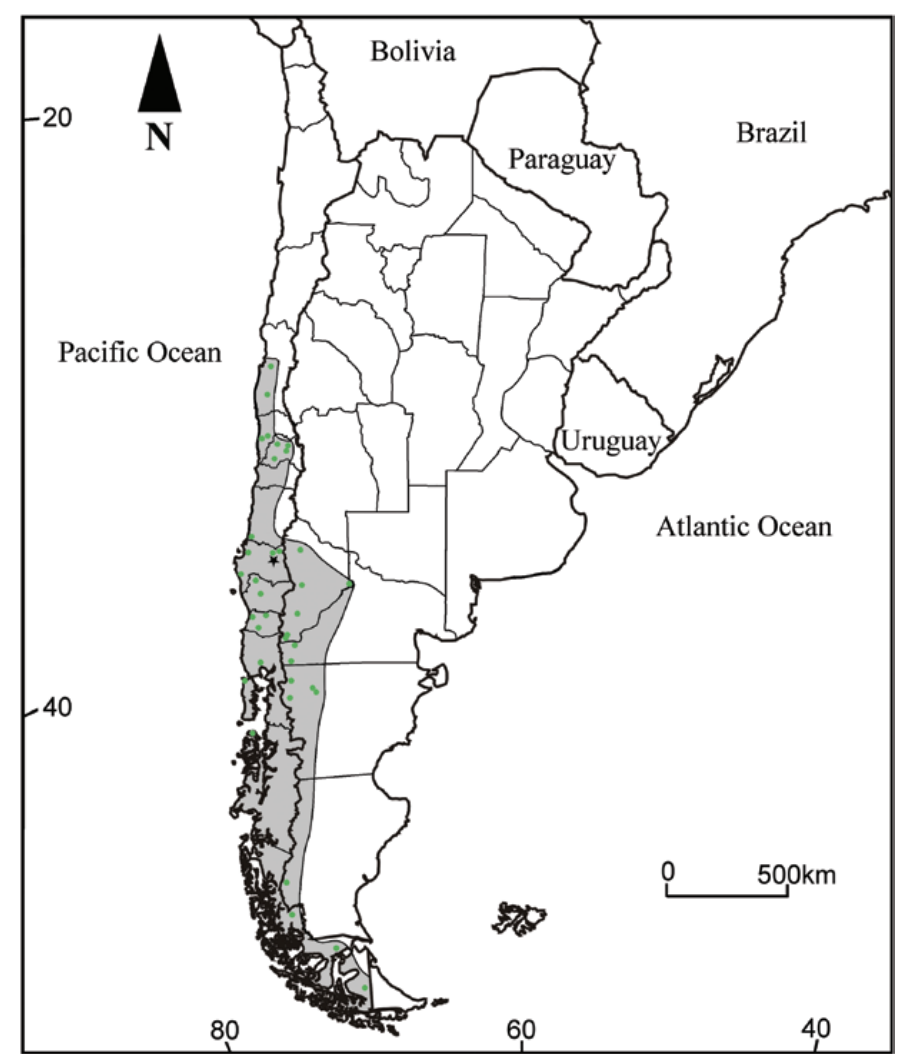

Fig. 3.-Geographic distribution of Lasiurus varius. The star indicates the type locality: Antuco, Biobío, Chile. Map drawn by M. Mónica Díaz. 
del Fuego, citing Dabbene (1902) who mentioned the presence of Atalapha borealis in Ushuaia (Tierra del Fuego, Argentina) and suggested that it was probably imported by some ship; no voucher specimens are known from this area.

Tamayo and Pérez D'Angello (1979) postulated the following hypotheses to explain the presence of $L$. varius south of the Strait of Magellan: a) the species is resident of the region but has not been observed; b) it is not a resident and collected specimens correspond to passive or accidental transportation; c) it performs regular seasonal movements to the south during the warmer season; d) it does not perform regular seasonal movements to the south, but in the warmer season it occasionally expands its distributional area. To date, none of these hypotheses have been rejected. Fossils for $L$. varius are not known.

\section{FORM AND FUNCTION}

Form. - The dental formula of Lasiurus varius is I 1/3, C $1 / 1, \mathrm{P} 2 / 2, \mathrm{M} 3 / 3$, total 32. Upper incisor is triangular and inclined inward, its internal face is furrowed, and its base is in contact with the upper margin of the cingulum of the canine; the canines are long and sharply pointed; the P1 is small, rounded, and displaced to the lingual side of the toothrow so that the canine and $\mathrm{P} 2$ are in contact with one another, and P1 is not visible in lateral view. P2 is well developed and unicuspidate. M1 and M2 are well developed; the cusps form a "W," the protocone is elevated and sharpened, and the hypocone absent; M3 has only two commissures. The lower inner incisors are trilobed, while the others are bilobed; the incisors form a continuous row that completely fills the space between the canines; $\mathrm{p} 1$ is small (p2 is more than twice as large as p1), and both have small paraconids and metaconids; trigonid of $\mathrm{m} 1$ and $\mathrm{m} 2$ is about the same size as the talonid; the talonid of $\mathrm{m} 3$ is much larger than the trigonid because the hypoconid and entoconid are closer to each other, and the protoconid and metaconid are well separated (Barquez et al. 1999). The $\mathrm{p} 3$ and the lower canines are comparatively longer than in L. blossevillii (Giménez and Giannini 2011).
According to Mann Fischer (1978), this species has an extraordinarily long third finger, and an equally long and narrow dactylopatagium, which favors fast flight speeds and allows travel of long distances. This long third digit creates difficulty in the complete flexing of the wing at rest. However, the advanced elasticity of the patagial membranes combined with a unique mechanisms of passive flexion of the forearm over the arm, based on muscles that extend between the distal end of the humerus and the carpus, acting like ligaments automatically flex the hand when the forearm is folded.

According to Kunz (1982), bats that use external roosts, including L. borealis, L. varius, and the North American hoary bat $L$. cinereus, have typically thick, long, woolly pelage and probably benefit from increased insulation. Male individuals of L. varius have more pronounced coloration tones than females (Rodríguez-San Pedro et al. 2014).

The intestines have a reduced length of $120 \mathrm{~mm}$ on average, which is a 3:1 proportion in relation to the total length of the body (Mann Fischer 1978). A highly vascularized "adipose tissue" mass is found on the interscapular dorsal area, as a metabolic reserve for hibernation (Mann Fischer 1978). Typically, female bats have two mammae but females of the genus Lasiurus have four (Hayssen et al. 1993).

Function.-Canals et al. (2005) estimated the size of the heart and lungs of several species of bats including Lasiurus varius from Chile (identified as L. borealis). They concluded that bats have the largest relative heart and lung size of all mammals, associated with the high energetic costs of flight. The heart mass of $L$. varius was estimated as $1.55 \pm 0.27 \%$ of body mass, and the relative lung size as $0.064 \pm 0.004 \mathrm{~cm}^{3} / \mathrm{g}$.

Studies of echolocation of insect-eating bats by Schnitzler and Kalko (2001) reported that bats hunting in open, uncluttered space, high above the ground or canopy and far from obstacles, are found mainly in four families and included the evening bats (family Vespertilionidae, genus Lasiurus). They indicated that these bats, when searching for insects, have no masking problem as long as the emitted signal does not overlap the returning insect echo. However, they often have the problem of rather small

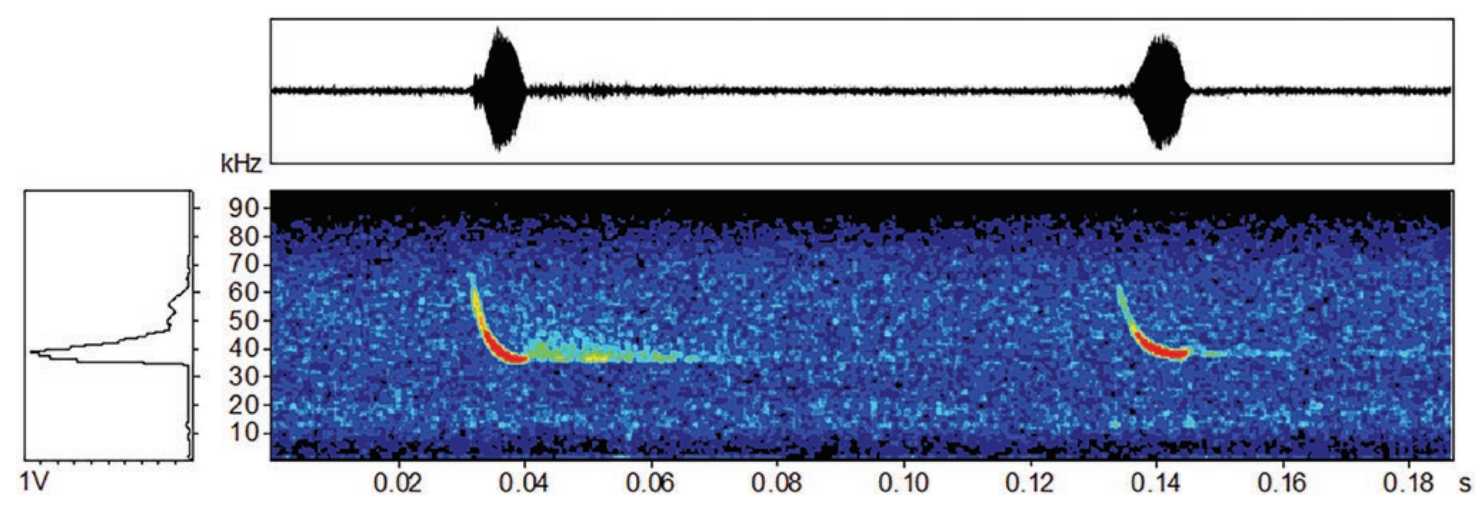

Fig. 4.-Sonogram of Lasiurus varius from the coast of the Biobío region, Central Chile. Y-axis represents frequencies (kHz) and X-axis represents time (s). Spectrogram was created using Avisoft SAS-Lab Pro V5.2.07 (Avisoft Bioacoustics, Berlin, Germany). Parameters were: fast Fourier transform length 256 ; frame size $100 \%$; overlap $75 \%$. 
prey being sparsely distributed in a large space, requiring the coverage of a large search area to find an insect.

The echolocation calls of $L$. varius contain a single harmonic and are characterized by a downward frequency modulation at the beginning of the signal, followed by a narrowband quasi-constant frequency component (Ossa 2010; Ossa et al. 2010; Rodríguez-San Pedro and Simonetti 2013a, 2014). Search calls of 28 individuals from central Chile (Ossa et al. 2010; Rodríguez-San Pedro and Simonetti 2014) consisted of medium $(7.6 \pm 0.2 \mathrm{~ms})$ broadband signals sweeping down between $52.2 \pm 0.8$ and $33.1 \pm 0.3 \mathrm{kHz}$, with most energy at 36.4 $\pm 0.3 \mathrm{kHz}$ (Fig. 4). Variations in search phase pulses according to the degree of clutter have been described (Rodríguez-San Pedro and Simonetti 2014).

\section{ONTOGENY AND REPRODUCTION}

A pregnant female with two embryos was captured on 22 November 1979 and a juvenile at the end of February in Río Negro (Argentina-Barquez et al. 1999); pregnant females were collected in Neuquén (Argentina) on 3 December 1991 (Mares et al. 1995). One of us (GO) captured two pregnant females during November 2009 in Santiago, Chile and Mann Fischer (1978) reported males with descended and enlarged testes from central Chile during the months of August and September. Females of the genus Lasiurus have four mammae and generally give birth to more than two young (Barquez et al. 1999). L. varius has a wide discoidal placenta and typically gives birth to twins (Mann Fischer 1978; Galaz and Yañez 2009). Neonates of Lasiurus have fine hair at birth and open their eyes at 10-12 days (Hayssen et al. 1993).

\section{ECOLOGY}

Members of the genus Lasiurus typically roost among leaves in densely foliated tree canopies and usually are solitary or form small family groups (Kunz and Lumsden 2003). L. varius has been found in day roosts in trees and, less commonly, on rocks along the coast of Chile (Mann Fischer 1978). Rau and Yañez (1979) mentioned specimens from Parque Nacional "Torres de Paine" (Ultima Esperanza Province, XII Region) roosting in branches of a fruit tree; a specimen was captured as it roosted with two other bats of the same species, in a small artificial conifer forest near a road in Chile, about $30 \mathrm{~m}$ from the coast (Tamayo and Pérez D’Angello 1979). Although Rodríguez-San Pedro et al. (2014) considered L. varius as solitary, in National Park Los Glaciares, Argentina, a group of four individuals was reported from Santa Cruz Province roosting in an apple tree (Malus domestica Rosaceae-Díaz et al. 2017).

Giménez and Giannini (2011) state that in Argentina $L$. varius is endemic to the Patagonian temperate rainforest and adjacent areas of the Patagonian steppe, and allopatric with the other three species of the genus (the southern yellow bat L. ega,
L. villosissimus, and L. blossevillii). However, in Chile this species was recorded to be sympatry with $L$. villosissimus at several localities (Galaz et al. 2009; Rodríguez-San Pedro and Simonetti 2013b). In Argentina, L. varius was collected with the southern big-eared brown bat Histiotus magellanicus and the Chilean myotis Myotis chiloensis in an area of Patagonian forest dominated by Nothofagus pumilio, N. betuloides, and Drymis winteri (Díaz et al. 2017). In Chile, it is associated with sclerophyllous forests in Central Chile; Valdivian temperate forests elsewhere, where it is often located in tree branches and hollow trunks, and in pine or eucalyptus plantations, or along vegetation edges, but also within the interior of the habitats (Rodríguez-San Pedro and Simonetti 2013b; Rodríguez-San Pedro et al. 2014). In the interior habitats of pine plantations, the high activity levels observed suggest that L. varius along with the small big-eared brown bat, Histiotus montanus, and the Chilean myotis not only pass through exotic plantations, but that they are active in these habitats commuting and feeding (Rodríguez-San Pedro and Simonetti 2013b).

The high activity of $L$. varius observed in local human settlements could be explained by its ability to fly in open spaces and its reliance on insects that accumulate around streetlights (Jung and Kalko 2010; Rodríguez-San Pedro and Simonetti 2013b). Medium-size fast-flying bats, such as those of the genus Lasiurus, typically fly back and forth in straight flight along rows of streetlights, patrol the street and dive toward insects in the light cone; this behavior is the most characteristic of bats that hunt near lights (Rydell 2006). L. varius is a fast-flying species with low maneuverability, expected to be clutter-sensitive (Schnitzler et al. 2003; Rodríguez-San Pedro and Simonetti 2014, 2015). In the clutter of plantations it uses service roads as flyways and adjusts its echolocation calls (Rodríguez-San Pedro and Simonetti 2014, 2015).

There are almost no studies about diet of $L$. varius but, according to Mann Fischer (1978) it feeds on voluminous prey such as nocturnal Lepidoptera and Coleoptera. Giménez and Giannini (2011) analyzed statistically the relationships between the use of space and resources by small and large species of Lasiurus that inhabit the South American Southern Cone. They predicted that the allopatric L. blossevillii and L. varius would show little differences in type of prey (e.g., proportion of small versus large or soft- versus hard-bodied insects), as these differences would be primarily due to local prey availability in the regions they inhabit.

The typical solitary behavior of species of Lasiurus and their tree roosting habits (Mann Fisher 1978) make their contact with humans and domestic animals infrequent; and could account for the uncommon submissions of Lasiurus for rabies diagnosis (de Mattos et al. 2000). In Chile, in 41 isolates of rabies virus from insectivorous bats characterize using eight anti-nucleoprotein monoclonal antibodies (N-Mabs) and nucleotide sequence analysis, only four were genetically associated with Lasiurus (Yung et al. 2002). Rabies lineages from other bat species have been found in genus Lasiurus, suggesting cross-species transmission, contrasting with a report from North America, where Lasiurus 
are more likely to be donors than recipients of spillover (Escobar et al. 2015).

\section{GENETICS}

The karyotype of Lasiurus varius is unknown. The phylogenetic position of $L$. varius varies among loci examined; with $N D 2$ (NADH dehydrogenase 2) and $D B Y$ (dead box Y) it is well supported as sister to the clade containing the other species of red bat (as defined by Baird et al. 2015), whereas with Cytb it is sister to L. blossevillii with only strong maximum likelihood support, and with ND1 it is sister to a clade containing L. borealis, Pfeiffer's red bat L. pfeifferi, and the Seminole bat L. seminolus with only strong Bayesian support (Baird et al. 2015). The phylogenetic position from the combined analysis of sequence data from these four loci strongly supports $L$. varius as sister to a clade containing the other species of red bats (Baird et al. 2015).

\section{CONSERVATION}

Lasiurus varius is considered as "Least Concern" by the International Union for Conservation of Nature and Natural Resources in the IUCN Red List of Threatened Species because of its wide distribution and presumed large population size (Solari 2018). In Chile, L. varius was evaluated in the $12^{\circ}$ process of species classification as "Least Concern" (Ministerio de Medio Ambiente 2015). In Argentina, it was not evaluated and is considered as belonging to "Data Deficient" category (Díaz 2012).

\section{REMARKS}

Several authors have misinterpreted the red phase of some specimens and populations of Lasiurus blossevilli as corresponding to Lasiurus varius resulting in an erroneous and confusing interpretation of the general distribution of $L$. varius in some of the earlier publications. For example, Cabrera (1958) established that L. varius was found from southern Peru southward into Chile to the province of Valdivia, and in western Argentina, because of the inclusion of red phase specimens of $L$. borealis (Barquez et al. 1999). Anthony (1923:9) erroneously reported L. varius from Colombia but stating that: "Owing to lack of comparative material and the apparent confusion of earlier writers in dealing with the reddish South American Lasiuri, it is impossible to do more than adopt some such temporary expedient." Olrog (1959) mentioned specimens of $L . b$. varius from the provinces of Tucumán and Jujuy, in northwestern Argentina, which were re-identified as $L$. b. blossevillii in Barquez et al. (1999). Rodríguez-San Pedro and Allendes (2016) suggested that the reasons some authors (Mann Fischer 1978; Galaz and Yáñez 2006; Galaz et al. 2009) included northern Chile as part of the "potential" distribution of $L$. varius, was perhaps based on the fact that they considered $L$. borealis was a single species, broadly distributed from North America south to South America.

\section{ACKNOWLEDGMENTS}

We thank the curators Jhoann Luis Canto Hernandez of the Museo Nacional de Historia Natural (Santiago, Chile) and Guillermo D'Elia of the Colección de Mamíferos de la Universidad Austral de Chile who provided access for the examination of specimens of Lasiurus varius.

\section{LITERATURE CITED}

Anthony, H. E. 1923. Mammals from Mexico and South America. American Museum Novitates 54:1-10.

BAIRD, A. B., et al. 2015. Molecular systematic revision of tree bats (Lasiurini): doubling the native mammals of the Hawaiian Islands. Journal of Mammalogy 96:1255-1274.

Baker, R. J., J. C. Patton, H. H. Genoways, and J. W. Bickham. 1988. Genic studies of Lasiurus (Chiroptera: Vespertilionidae). Occasional Papers the Museum Texas Tech University 117:1-16.

Barquez, R. M. 1987. Los Murciélagos de Argentina. Ph.D. dissertation, Universidad Nacional de Tucumán, San Miguel de Tucumán, Argentina.

Barquez, R. M., M. N. Carbajal, M. Failla, and M. M. Díaz. 2013. New distributional records for bats of the Argentine Patagonia and the southernmost known record for a molossid bat in the world. Mammalia 77:119-126.

Barquez, R. M., and M. M. Díaz. 2009. Clave de Identificación de los Murciélagos de Argentina. Publicación del PCMA (Programa de Conservación de los Murciélagos de Argentina), Tucumán, Argentina.

Barquez, R. M., M. A. Mares, and J. K. Braun. 1999. The bats of Argentina. Special Publications, Museum of Texas Tech University 42:1-275.

Cabrera, A. 1958. Catálogo de los mamíferos de América del Sur. Revista del Museo Argentino de Ciencias Naturales "Bernardino Rivadavia" Ciencias Zoológicas 4:1-308.

Canals, M., C. Atala, B. Grossi, and J. Iriarte-Díaz. 2005. Relative size of hearts and lungs of small bats. Acta Chiropterologica $7: 65-72$.

Dabbene, R. 1902. Fauna magellanica. Mamíferos y Aves de la Tierra del Fuego é islas adyacentes. Anales del Museo Nacional de Buenos Aires 3:341-409.

de Mattos, C. A., M. Favi, V. Yung, C. Pavletic, and C. C. De Mattos. 2000. Bat rabies in urban centers in Chile. Journal of Wildlife Diseases 36:231-240.

DíAz, M. M. 2012. Orden Chiroptera. Pp. 67-80 in Libro rojo, mamíferos amenazados de la Argentina (R. A. Ojeda, V. Chillo, and G. B. Diaz Isenrath, eds.). SAREM (Sociedad Argentina para el Estudio de los Mamíferos), Argentina.

Díaz, M. M., L. F. Aguirre, and R. M. Barquez. 2011. Key to the bats of southern cone of South America (Argentina-Bolivia-Chile-ParaguayUruguay). Publicación especial PCMA (Programa de Conservación de los Murciélagos de Argentina)-PCMB (Programa para la Conservación de los Murciélagos de Bolivia), Centro de Estudios de Biología Teórica y Aplicada, Bolivia.

Díaz, M. M., S. Solari, L. F. Aguirre, L. Aguiar, and R. M. Barquez. 2016. Clave de identificación de los murciélagos de Sudamérica/ Chave de indentificação dos morcegos da América do Sul. Publicación Especial Nro 2 PCMA (Programa de Conservación de los Murciélagos de Argentina), Editorial Magna Publicaciones, Tucumán, Argentina. 
Díaz, M. M., A. Valenzuela, S. Sturzenbaum, and R. M. Barouez. 2017. New records of bats (Chiroptera) from Santa Cruz Province (Argentina) and the southernmost record of Lasiurus varius for Argentina. CheckList 13:397-401.

Dobson, G. E. 1878. Catalogue of the Chiroptera in the Collection of the British Museum. British Museum (Natural History), London, United Kingdom, XLII + 567 pp., 29 pls.

Escobar, L. E., A. Townsend Peterson, M. Favi, V. Fing, and G. Medina-Vogel. 2015. Bat-borne rabies in Latin America. Revista del Instituto de Medicina Tropical São Pablo 57:63-72.

FitZINGER, L. J. 1870. Kritische Durchsict der Ordnung der Flatterthiere oder Handflögler (Chiroptera). Familie der Fledermäuse (Vespertiliones). V. Abtheilung. Sitzungsberichte der Kaiserlichen Akademie der Wissenschaften 62:253-438.

Galaz, J. L., and J. YÁñEZ. 2006. Los murcielagos de Chile: Guia para su reconocimiento. Centro de Ecología Aplicada, Santiago, Chile.

Galaz, J. L., J. Yañez, A. Gantz, and D. R. Martinez. 2009. Orden Chiroptera. Pp. 67-89 in Mamíferos de Chile (A. Muñoz-Pedreros and J. Yañez, eds.). CEA (Centro de Estudios Agrarios y Ambientales) Ediciones, Valdivia, Chile.

Gantz, A. G., and D. R. Martínez. 2000. Quirópteros de Chile. Pp. 5366 in Biología de Mamíferos de Chile (A. H. Muñoz and J. L. Yáñez, eds.). Editorial Centro de Estudios Agrarios (CEA), Valdivia, Chile.

Gardner, A. L., and C. O. HANdley, JR. 2008. Genus Lasiurus Gray, 1831. Pp. 457-468 in Mammals of South America, volume 1 - marsupials, xenarthrans, shrews, and bats (A. L. Gardner, ed.). University of Chicago Press, Chicago, Illinois.

Giménez, A., and N. P. Giannini. 2011. Morphofunctional and geographic segregation among species of Lasiurine bats (Chiroptera: Vespertilionidae) from the South American Southern Cone. Mammalia 75:173-179.

Giménez, A., N. Giannini, M. Schiaffini, and G. Martin. 2012. Records of the rare Histiotus magellanicus (Chiroptera, Vespertilionidae) and other bats from central Patagonia, Argentina. Mastozoología Neotropical 19:213-224.

Hall, E. R., and J. K. Jones, JR. 1961. North American yellow bats, "Dasypterus", and a list of the named kinds of the genus Lasiurus Gray. University of Kansas Publications, Museum of Natural History 14:73-98.

HANDlEy, C. O., JR. 1996. New species of mammals from northern South America: bats of the genera Histiotus Gervais and Lasiurus Gray (Mammalia: Chiroptera: Vespertilionidae). Proceedings of Biological Society of Washington 109:1-9.

Hayssen, V., A. van Tienhoven, and A. van Tienhoven. 1993. Asdell's patterns of mammalian reproduction. A compendium of speciesspecific data. Cornell University Press, Ithaca, New York.

Iriarte, A. 2008. Los mamíferos de Chile. Lynx Ediciones, Barcelona, Spain.

JUNG, K., and E. K. V. KALKo. 2010. Where forest meets urbanization: foraging plasticity of aerial insectivorous bats in an anthropogenically altered environment. Journal of Mammalogy 9:144-153.

Koopman, K. F. 1967. The southernmost bats. Journal of Mammalogy 48:487-488

Koopman, K. F. 1993. Order Chiroptera. Pp. 137-242 in Mammal species of the world: a taxonomic and geographic reference (D. E. Wilson and D. M. Reeder, eds.). 2nd ed. Smithsonian Institution Press, Washington, D.C.

Kunz T. H. 1982. Roosting ecology. Pp. 1-56 in Ecology of bats (T. H. Kunz, ed.). Plenum Press, New York.

KunZ, T. H., and L. F. Lumsden. 2003. Ecology of cavity and foliage roosting bats. Pp. 3-89 in Bat ecology. (T. H. Kunz and M. B. Fenton, eds.). University of Chicago Press, Chicago, Illinois.

Lesson, R.-P. 1836. Histoire naturelle générale et particulière des mammifères et des oiseaux découverts depuis la nort de Buffon. Mammifères. Pourrat Frères, Paris 5:1-512.

Lesson, R.-P. 1842. Nouveau tableau do Règne Animal. Mammifères. Arthus-Bertrand, Paris, 204 pp.

Mann Fischer, G. 1978. Los pequeños mamíferos de Chile. Gayana Zoología 40:1-342.
Mares, M. A., R. M. Barouez, and J. K. Braun. 1995. Distribution and ecology of some Argentine bats (Mammalia). Annals of Carnegie Museum 64:219-237.

MMA (Ministerio de Medio Ambiente). 2015. $12^{\circ}$ Proceso de Clasificación. Gobierno de Chile. http://www.mma.gob.cl/clasificacionespecies/ duodecimo-proceso.htm.

Morales, J. C., and J. W. Bickham. 1995. Molecular systematics of the genus Lasiurus (Chiroptera: Vespertilionidae) based on restriction-site maps of the mitochondrial ribosomal genes. Journal of Mammalogy 76:730-749.

Muñoz, A., and J. Yañez. 2009. Mamíferos e Chile. CEA (Centro de Estudios Agrarios y Ambientales) Ediciones, Valdivia, Chile.

Novaes, R. L. M., G. T. Garbino, V. C. Claudio, and R. Moratelli. 2018. Separation of monophyletic groups into distinct genera should consider phenotypic discontinuities: the case of Lasiurini (Chiroptera: Vespertilionidae). Zootaxa 4379:439-440.

Olrog, C. C. 1959. Notas mastozoológicas. IL Sobre la colección del Instituto Miguel Lillo. Acta Zoológica Lilloana 17:403-419.

OsGood, W. H. 1943. The mammals of Chile. Field Museum of Natural History, Zoological Series 30:1-268.

Ossa, G. 2010. Métodos bioacústicos: una aproximación a la ecología de comunidades de murciélagos en las eco-regiones mediterránea y el bosque templado de Chile. Pontificia Universidad Católica de Chile, Santiago, Chile.

Ossa, G., F. Díaz, O. O’Hrens, J. Laker, and C. Bonacic. 2010. Conociendo los murciélagos a través de sus ultrasonidos. La Chiricoca $11: 26-31$.

Peters, W. 1861. Eine Ubersicht der von Hrn. Dr. Gundlach beobachteten Fledertheire auf Cuba mit. Die nach dem Leben gemachten Bescreibungen de Hrn. Dr. Gundlach wurden vorgelegt, welche nebst den Original exemplaren durch Hrn. Geheimerath Sezekorn in Kassel zur näheren Vergleichung übersandt worden waren. Monatsberichte der Königlichen Preussische Akademie des Wissenschaften zu Berlin 1862:149-156.

PoepPig, E. F. 1830. Doctor Pöppig's naturhistorische Berichte aus Chile. Notizen aus dem Gebiete der Natur- und Heilkunde, no. 586, columns 209-224.

Poeppig, E. F. 1835. Reise in Chile, Peru und auf dem Amazonenstrome während der Jahre 1827-1832. F. Fleischer, Leipzing 1:464

RAU, J. R., and J. YAÑEZ. 1979. Nuevos registros de Lasiurus borealis en Magallanes. Noticiario Mensual, Museo Nacional de Historia Natural 274-275:13-14.

Redford, K. H., and J. F. Eisenberg. 1992. Mammals of the Neotropics, the Southern Cone: Chile, Argentina, Uruguay. University of Chicago Press, Chicago, Illinois.

Rodríguez-San Pedro, A., and J. L. Allendes. 2016. Lasiurus borealis (Müller, 1776): una especie erróneamente reconocida dentro de la quiropterofauna de Chile. Biodiversity and Natural History 2: 10-12.

Rodríguez-San Pedro, A., J. L. Allendes, P. Carrasco-Lagos, and R. A. Moreno. 2014. Murciélagos de la Región Metropolitana de Santiago, Chile. Seremi del Medio Ambiente Región Metropolitana de Santiago, Universidad Santo Tomás y Programa para la Conservación de los Murciélagos de Chile (PCMCh), Santiago, Chile.

Rodríguez-San Pedro, A., and J. A. Simonetti. 2013a. Acoustic identification of four species of bats (Order Chiroptera) in Central Chile. Bioacoustics 22:165-172.

Rodríguez-San Pedro, A., and J. A. Simonetti. 2013b. Foraging activity by bats in a fragmented landscape dominated by exotic pine plantations in central Chile. Acta Chiropterologica 15:393-398.

Rodríguez-San Pedro, A., and J. A. Simonetti. 2014. Variation in search-phase calls of Lasiurus varius (Chiroptera: Vespertilionidae) in response to different foraging habitats. Journal of Mammalogy 95:1004-1010.

Rodríguez-San Pedro, A., and J. A. Simonetti. 2015. Does understory clutter reduce bat activity in forestry pine plantations? European Journal Wildlife Research 61:177-179. 
Rydell, J. 2006. Bats and their insect prey at streetlights. Pp. 43-61 in Ecological consequences of artificial night lighting (C. Rich and T. Longcore, eds.). Island Press, Washington, D.C.

Schnitzler, H.-U., and E. K. V. KalKo. 2001. Echolocation by insecteating bats. Bioscience 51:557-569.

Schnitzler, H.-U, C. F. Moss, and A. Denzinger. 2003. From spatial orientation to food acquisition in echolocation bats. Trends in Ecology and Evolution 18:386-394.

Shump, K. A., JR., and A. U. Shump. 1982. Lasiurus borealis. Mammalian Species 183:1-6.

Simmons, N. B. 2005. Order Chiroptera. Pp. 312-529 in Mammal species of the world: a taxonomic and geographic reference (D. E. Wilson and D. M. Reeder, eds.). 3rd ed. John Hopkins University Press, Baltimore, Maryland.

SolarI, S. 2018. Lasiurus varius. The IUCN Red List of Threatened Species 2018: e.T136690A22040066. http://dx.doi.org/ 10.2305/ IUCN.UK.2018-2.RLTS.T136690A22040066.en. Accessed 27 September 2019.

TAmayo, H. M., and V. Pérez D’Angello. 1979. Hallazgo del murciélago colorado, Lasiurus borealis varius (Poeppig, 1835) en Magallanes y consideraciones acerca de la distribución de los Lasiurus (Chiroptera,
Vespertilionidae). Noticiario Mensual, Museo Nacional de Historia Natural, Santiago 273:3-10.

Thomas, O. 1902. On Mammals collected at Cruz del Eje, Central Cordova, by Mr. P. O. Simons. Annals and Magazine of Natural History Series 7 9:237-245.

TrouessarT, E.-L. 1897. Catalogus mammalium tam viventium qua m fossilium. Fasciculus I. Primates, Prosimiae, Chiroptera, Insectivora. R. Friedländer \& Sohn, Berolini, l:vi +218 pp.

Trouessart, E.-L. 1904. Catalogus mammalium tam viventium quam fossilium. Quinquennale supplementium, anno 1904, Fasc. 1, 1-228. R. Friedländer \& Sohn, Berolini, vii +929 pp.

Udrizar Sauthier, D. E., P. Teta, A. E. Formoso, A. Bernardis, P. Wallave, and U. F. J. Pardiñas. 2013. Bats at the end of the world: new distributional data and fossil records from Patagonia, Argentina. Mammalia 77:307-315.

Yung, V., M. FAVI, and J. Fernández. 2002. Genetic and antigenic typing of rabies virus in Chile. Archives Virology 147:2197-205.

Associate Editor of this account was C. William Kilpatrick. Editor was Meredith J. Hamilton. 